\title{
Serological Relationships Between the Cylindrical Inclusion Proteins of Potyviruses
}

\author{
John Hammond
}

USDA-ARS, U.S. National Arboretum, Floral and Nursery Plants Research Unit, Beltsville, MD 20705.

Accepted for publication 8 June 1998.

\begin{abstract}
Hammond, J. 1998. Serological relationships between the cylindrical inclusion proteins of potyviruses. Phytopathology 88:965-971.

Antisera to the cytoplasmic inclusion proteins (CIPs) of bean yellow mosaic (BYMV), clover yellow vein (ClYVV), turnip mosaic (TuMV), sweet potato feathery mottle (SPFMV), and maize dwarf mosaic (MDMV) potyviruses were used to examine the relationships between the CIPs of 18 potyviruses. The antisera to CIPs of BYMV, CIYVV, TuMV, and SPFMV cross-reacted to most or all of the purified CIPs tested in western blot assays. The MDMV CIP antiserum reacted significantly only to

amino acid sequences of the CI genes of 11 well-characterized potyviruses suggested that epitopes specific for individual potyviruses are primarily in the C-terminal domains of the CIP, whereas epitopes shared among different viruses are clustered in the N-terminal domains. The most highly conserved predicted epitope overlaps the nucleotide binding motif of the N-terminal helicase domain of the CIP. Antibodies to this domain will probably be present in antisera to any potyvirus CIP and contribute to the cross-reactivity observed. Differences in the C-terminal domains may correlate with interactions between the CIP and coat protein necessary for replication and movement.
\end{abstract} the MDMV and sorghum mosaic virus CIPs. Reactivity of antisera to CIPs of dicot-infecting viruses was generally higher with CIPs of other dicot-infecting than with monocot-infecting potyvirus CIPs. Analysis of
Additional keywords: predicted antigenicity.
The potyviruses form the largest known group of plant viruses, with about 180 members that infect a broad range of plant species (42). One of the unique features of potyvirus infection is the production of characteristic cytoplasmic inclusions (CI), which have been useful as a diagnostic tool (14). Variations in the structure of the CI (also called pinwheel inclusions or cylindrical inclusions) have allowed the grouping of potyvirus isolates into subdivisions I to IV $(10,11,13)$, although different isolates of the same virus have been reported to induce different types of CI. This is presumably due to amino acid sequence differences affecting CI structure (12). It was the fact that the characteristic form of the CI of individual potyvirus isolates is maintained in different hosts and that different potyviruses each induce their own typical form of $\mathrm{CI}$ in a common host that led to the conclusion that CIs were virus-encoded rather than a host cytopathic effect (10). This was proven when CI protein (CIP) was shown to be one of the in vitro translation products of the potyvirus genome (9).

It had previously been established that CIP is serologically unrelated to either the potyviral coat protein $(\mathrm{CP})$ or to normal host proteins, using antisera prepared against whole purified CI $(22,37)$. The CIPs of different viruses were shown to be distinct, with antisera to tobacco etch virus (TEV) and turnip mosaic virus (TuMV) CIs reacting only with the homologous antigen; some cross-reaction of antisera raised to three other potyviral CIs was apparent as spurring visible in gel diffusion assays using sodium dodecyl sul-

Corresponding author: J. Hammond; E-mail address: jhammond @ asrr.arsusda.gov

Mention of a trade name, proprietary product, or specific equipment does not constitute a guarantee or warranty by the U.S. Department of Agriculture and does not imply approval to the exclusion of other produts that may be suitable.

Publication no. P-1998-0716-03R

This article is in the public domain and not copyrightable. It may be freely reprinted with customary crediting of the source. The American Phytopathological Society, 1998. fate (SDS)-denatured CIP preparations (37). McDonald and Hiebert (32) used gel diffusion assays to show that there was less serological variability between the CIPs of three TuMV isolates than between the CPs, despite morphological distinction of the CI of one isolate. This finding was confirmed with three distinct cucurbitinfecting potyviruses by Suzuki et al. (44), using western blots. Similar results were obtained by Yeh and Gonsalves (45) and Quiot-Douine et al. (38). This has been supported by the greater conservation in amino acid sequence between CIPs than between the CPs of different potyviruses (40).

The presence of CIs in plant tissue has been utilized for diagnosis of potyviral infections by microscopy (14), by various forms of enzyme-linked immunosorbent assay (ELISA) $(34,45)$, and by electrophoresis (2). Alper et al. (2) were able to detect and differentiate three potyviruses infecting bulbous iris on the basis of differences in the molecular weight of their respective CIPs; however, Jensen et al. (24) found variability in both the CIPs and CPs of different isolates of several potyviruses infecting graminaceous species that suggested caution in the interpretation of results obtained by this method. Mowat et al. (34) prepared an antiserum to narcissus yellow stripe virus CIP, because they were able to purify CIs, but were unable to purify virions; the antiserum to CIP thus allowed ELISA detection of infection. They also showed that antiserum to the CIP reacted specifically with the homologous CIP on western blots (34).

Jensen and Staudinger (25) used western blots with antisera to the CIPs of five isolates described as sugarcane mosaic virus (SCMV) and one isolate of maize dwarf mosaic virus (MDMV) to examine the relationships between these isolates. They found that the isolates could be separated into three serological groups; within groups there were strong cross-reactions, and there were moderate crossreactions between two of the groups, with no cross-reactions to the third group. The cross-reactions observed with CIPs correlated with those observed with CPs (25). Similar western blot differentiation of cross-reactivity was observed with three distinct potyviruses infecting cucurbits (44). In a preliminary report, it was noted that four antisera to distinct potyviruses cross-reacted on western 
blots with 17 different potyvirus CIPs, while a fifth antiserum reacted with fewer; less cross-reactivity was observed on dot-blots (16). Baunoch et al. (5) have since reported that antisera to three potyvirus CIPs reacted with a large number of overlapping hexapeptides corresponding to the amino acid sequence of the TEV CIP and that there were some antigenically conserved regions recognized by antisera to all three viruses. In this report, the crossreactivity of antisera to the CIPs of five potyviruses are reported in more detail, and comparisons are made to the predicted antigenic sites of 11 sequenced potyvirus CIP genes. The significance of the apparent greater serological relationship among epitopes of the $\mathrm{N}$-terminal domain (helicase domain) $(15,28)$ than among the more virus-specific predicted epitopes in the $\mathrm{C}$-terminal domain of the CI is discussed.

\section{MATERIALS AND METHODS}

Viruses and CIP purification. Isolates of the following viruses were included in this study: asparagus virus 1 (AV-1); bean yellow mosaic virus (BYMV); clover yellow vein virus (CIYVV); iris mild mosaic virus (IMMV); iris severe mosaic virus (ISMV); pepper mottle virus (PepMoV); pokeweed mosaic virus (PkMV); pea seedborne mosaic virus (PSbMV); potato virus A (PVA); potato virus $\mathrm{Y}$ (PVY); sweet potato feathery mottle virus (SPFMV); tulip chlorotic blotch virus (TCBV); TEV; TuMV; tobacco vein mottling virus (TVMV); maize dwarf mosaic virus A (MDMV-A); johnsongrass mosaic virus (JGMV), formerly the MDMV-O strain of MDMV (41); and sorghum mosaic virus (SrMV), formerly a strain of sugarcane mosaic virus, SCMV-H (41). The sources of virus isolates used in this study and their propagation hosts are listed in Table 1. The CIPs were purified as described (21). Extracts of healthy turnip and Nicotiana $\times$ edwardsonii plants used as controls were purified by the same method; $N . \times$ edwardsonii extracts were used because preliminary experiments concentrated on isolates of TuMV, some of which were purified from $N . \times$ edwardsonii.

Preparations of CIPs were made to contain 2\% SDS and heated to $95^{\circ} \mathrm{C}$ until the turbid solution became clear, and then approximate concentrations were determined from the absorption at $280 \mathrm{~nm}$ (estimating that $1 \mathrm{mg}$ of CIP per $\mathrm{ml}$ absorbs 1.4 optical density units [OD] at $280 \mathrm{~nm}$ with a 1-cm path length). Preparations typically contained both virus and some host proteins as impurities, which precluded accurate spectrophotometric determination of CIP con- centration; preparations were, therefore, diluted to similar concentrations with $20 \mathrm{mM}$ Tris-HCl, $\mathrm{pH} \mathrm{8.2,} \mathrm{containing} \mathrm{2 \%} \mathrm{SDS.} \mathrm{Final}$ adjustment to approximately $1 \mathrm{mg} / \mathrm{ml}$ of the CIP band was determined by electrophoresis in polyacrylamide gels followed by staining with Coomassie blue and comparison of staining intensity of the CIP band with molecular weight marker standards (BioRad Laboratories, Richmond, CA). Extracts of healthy plants were not diluted, except by addition of an equal volume of dissociation buffer.

Antisera. Polyclonal rabbit antisera to CIPs of BYMV-G (35), CIYVV (35), and TuMV-T (37) were obtained from F. W. Zettler, University of Florida. Antiserum to the SPFMV isolate SPV-I was prepared at the American Type Culture Collection (ATCC PVAS396); the antigen was purified as described (21) and further purified by elution from preparative acrylamide gels (45). Antiserum to the CIP of MDMV Minnesota 11 isolate (25) was a gift of S. G. Jensen (USDA-ARS/University of Nebraska). Each antiserum was diluted 1:400 for use.

Electrophoresis and blotting. Electrophoresis was performed as described (19). Proteins were blotted from the acrylamide gels to either nitrocellulose (BA 85; Schleicher and Schuell, Inc., Keene, $\mathrm{NH}$ ) or polyvinylidene difluoride (Immobilon-P; Millipore Corp., Bedford, MA) membranes using a semidry blotting apparatus (American Bionetics, Emeryville, CA), and the western blots were developed as described $(17,20)$, using goat anti-rabbit antibodies conjugated to alkaline phosphatase (Kirkegaard and Perry, Gaithersburg, MD) diluted 1:2,500. Detection was with nitroblue tetrazolium and 5-bromo-4-chloro-3-indolyl phosphate (NBT/BCIP; Sigma Chemical Co., St. Louis). Two to five replications were carried out with each antiserum, with some membranes developed for longer times in order to reveal weaker reactions more clearly. Some membranes were treated by the Chloramine $\mathrm{T}$ procedure of Kumar et al. (27) to reveal the total protein banding patterns prior to serological probing.

Sequence analysis. CIP amino acid sequences analyzed were those of BYMV strain S (GenBank accession U47033), JGMV (Z26920), PepMoV (M96425), plum pox virus (PPV) (D13751) (31), PSbMV (D10930), PVA (Z21670), PVY (X12456) (39), SPFMV (D86371), TEV (M11458) (1), TuMV (D10927), and TVMV (X04083) (7). Analysis was performed using the PC-Gene package (IntelliGenetics, Inc., Mountain View, CA). Predictions of antigenicity and flexibility of subdomains were made using the programs ANTIGEN and FLEXPRO and the sequences aligned

TABLE 1 . Virus isolates used in this study

\begin{tabular}{|c|c|c|c|}
\hline Virus isolate & Source $^{a}$ & Origin $^{b}$ & Propagation host \\
\hline Asparagus virus $1-\mathrm{N}$ & Asparagus & California & Nicotiana benthamiana \\
\hline Bean yellow mosaic virus GDD ${ }^{c}$ & Gladiolus & Utah & N. benthamiana \\
\hline Clover yellow vein virus Pratt & & O. W. Barnett & N. benthamiana \\
\hline Iris mild mosaic virus Polar Ice & Bulbous iris & Washington & Bulbous iris \\
\hline Iris severe mosaic virus $\mathrm{P}$ & Pardancanda & Maryland & Belamcanda chinensis \\
\hline Pepper mottle virus NC165 & & J. W. Moyer & N. tabacum \\
\hline Pokeweed mosaic virus & Pokeweed & Maryland & Pokeweed \\
\hline Pea seedborne mosaic virus PV184 & & ATCC & Pea \\
\hline Potato virus A & & R. W. Goth & N. tabacum \\
\hline Potato virus Y 3 & & R. W. Goth & N. tabacum \\
\hline Sweet potato feathery mottle virus SPV-I ${ }^{\mathrm{d}}$ & & G. Thottappilly & N. benthamiana \\
\hline Tulip chlorotic blotch virus & & W. P. Mowat & N. benthamiana \\
\hline Tobacco etch virus PV-69 & & ATCC & N. tabacum \\
\hline Turnip mosaic virus PV-58 & & ATCC & Turnip \\
\hline Turnip mosaic virus PV-134 & & ATCC & Turnip \\
\hline Turnip mosaic virus Linc-3 & Tulip & Washington & Turnip \\
\hline Turnip mosaic virus MW & Tulip & Washington & N. benthamiana \\
\hline Tobacco vein mottling virus & & K. M. Franklin & N. tabacum \\
\hline Maize dwarf mosaic virus Minn 11 & & S. G. Jensen & Sorghum \\
\hline Johnsongrass mosaic virus (maize dwarf mosaic virus $\mathrm{O}$ ) & & S. G. Jensen & Sorghum \\
\hline Sorghum mosaic virus (sugarcane mosaic virus $\mathrm{H}$ ) & & S. G. Jensen & Sweet corn \\
\hline
\end{tabular}

a Source indicates the host plant from which viruses were isolated by J. Hammond.

b Origin denotes the donor or supplier of isolates or the geographical origin of those isolated by J. Hammond.

c Deposited at the American Type Culture Collection (ATCC) as ATCC PV-368.

d Deposited at the ATCC as ATCC PV-457. 
using CLUSTAL from the PC-Gene package. For the purposes of the sequence comparison and alignment, the PVA CIP sequence was truncated by 53 amino acids at the $\mathrm{C}$-terminus (to a $\mathrm{Q} / \mathrm{S}$ dipeptide) relative to the $\mathrm{C}$-terminus indicated in the GenBank annotations. This truncation would result in a CIP of 634 residues, more comparable with other CIPs. The JGMV CIP sequence was lengthened by 44 residues to a $\mathrm{Q} / \mathrm{I}$ dipeptide at the $\mathrm{N}$-terminal side of the position identified in the GenBank accession, resulting in an N-terminus comparable to those of other CIPs. Following initial analysis of the sequences, residues 1 to 300 of each sequence were reanalyzed using FLEXPRO.

\section{RESULTS}

Western blotting. Staining of gels with Coomassie blue (Fig. 1) or of membranes with Chloramine $\mathrm{T}$ (data not shown) showed that concentration of CIP in each preparation was closely comparable. Results from replicated experiments were similar, with minor differences due to times allowed for substrate development. Experiments with antisera to the CIPs of BYMV, ClYVV, TuMV, and SPFMV showed that there was broad cross-reactivity with the CIPs of other potyviruses (Fig. 1) (16). The BYMV CIP antiserum reacted strongly with the CIPs of TVMV and BYMV and weakly with those of PkMV, AV-1, and ISMV. There was obvious reaction with all other CIPs except MDMV and SrMV; there was no reaction with the healthy extracts (Fig. 1). The ClYVV CIP antiserum cross-reacted with all CIPs tested, although reactions with PkMV, $\mathrm{AV}-1$, and the cereal-infecting virus CIPs were notably weaker and the homologous reaction strongest; no reaction to healthy extracts was apparent (Fig. 1). Significant reactions of the TuMV CIP antiserum were observed with all CIPs tested, although reactions were weaker with the monocot-infecting viruses (Fig. 1). There was no apparent distinction using the TuMV CIP antiserum between TCBV and isolates of TuMV (data not shown), which have been shown to be related but serologically distinguishable using $\mathrm{CP}$ antisera and monoclonal antibodies (18). There were reactions of the TuMV CIP antiserum with both healthy extracts, but to bands of greater and lesser mobility than the CIPs of any of the viruses, and no reactions to equivalent bands were observed in the CIP preparations (Fig. 1). The SPFMV CIP antiserum reacted with all of the CIPs tested, with the homologous reaction being strongest (Fig. 1). In contrast, the MDMV CIP antiserum reacted strongly only with MDMV and SrMV CIPs; a weakly reactive band observed with all other CIP preparations tested was of uniform mobility (Fig. 1), whereas consistent differences in mobility were observed between the CIPs of different viruses (compare western blots and total protein stain) (Fig. 1). The quantitative differences in the reactions presumably reflect differences in the number of epitopes recognized by each antiserum, as the loadings of each CIP were similar, as shown by Chloramine $\mathrm{T}$ staining of membranes or Coomassie blue staining of a similar gel (Fig. 1).

Sequence analysis. The sequences of the CI genes of 11 potyviruses were examined for clues to the differential cross-reactivity of the individual CIP antisera. Predictions of antigenicity of continuous epitopes by the method of Hopp and Woods (23) are based on regions of high hydrophilicity and were obtained from the program ANTIGEN. The flexibility of CIP segments was predicted using the program FLEXPRO, based on the method of Karplus and Schultz (26). Using these methods, and overlaying the predicted domains on an amino acid alignment of the CIP sequences, it was apparent that a few predicted epitopes are conserved between the different CIPs (Fig. 2). In particular, the absolutely conserved sequence at residues 88 to 93 (relative to the PPV sequence) was identified by FLEXPRO as being among the 10 most flexible regions, and therefore, likely to be antigenic; this region overlaps the conserved nucleotide binding site GXXGXGKS identified in many viral proteins $(15,29)$. It is worthy of note that an additional residue (PPV CIP residue 94 and equivalent) is conserved and forms part of the predicted epitope in all but JGMV (Fig. 2). Several other regions predicted by FLEXPRO were partially conserved between the different sequences. (i) PPV residues 121 to 127 and similar regions of all but TuMV and JGMV CIPs, although the potential epitopes of SPFMV and TEV were not identified until only the N-terminal 300 residues were analyzed separately (thus excluding three C-terminal regions of greater flexibility in each case). (ii) At least five of PPV residues 140 to 147 are conserved with equivalent residues of TVMV, PVA, TEV, PVY, PepMoV, PSbMV, and JGMV. However, no epitope was predicted in PSbMV, even when only the N-terminal 300 residues were examined, despite identity to all seven residues identified as an epitope in PPV (Fig. 2). (iii) PPV residues 203 to 210 and their equivalents are

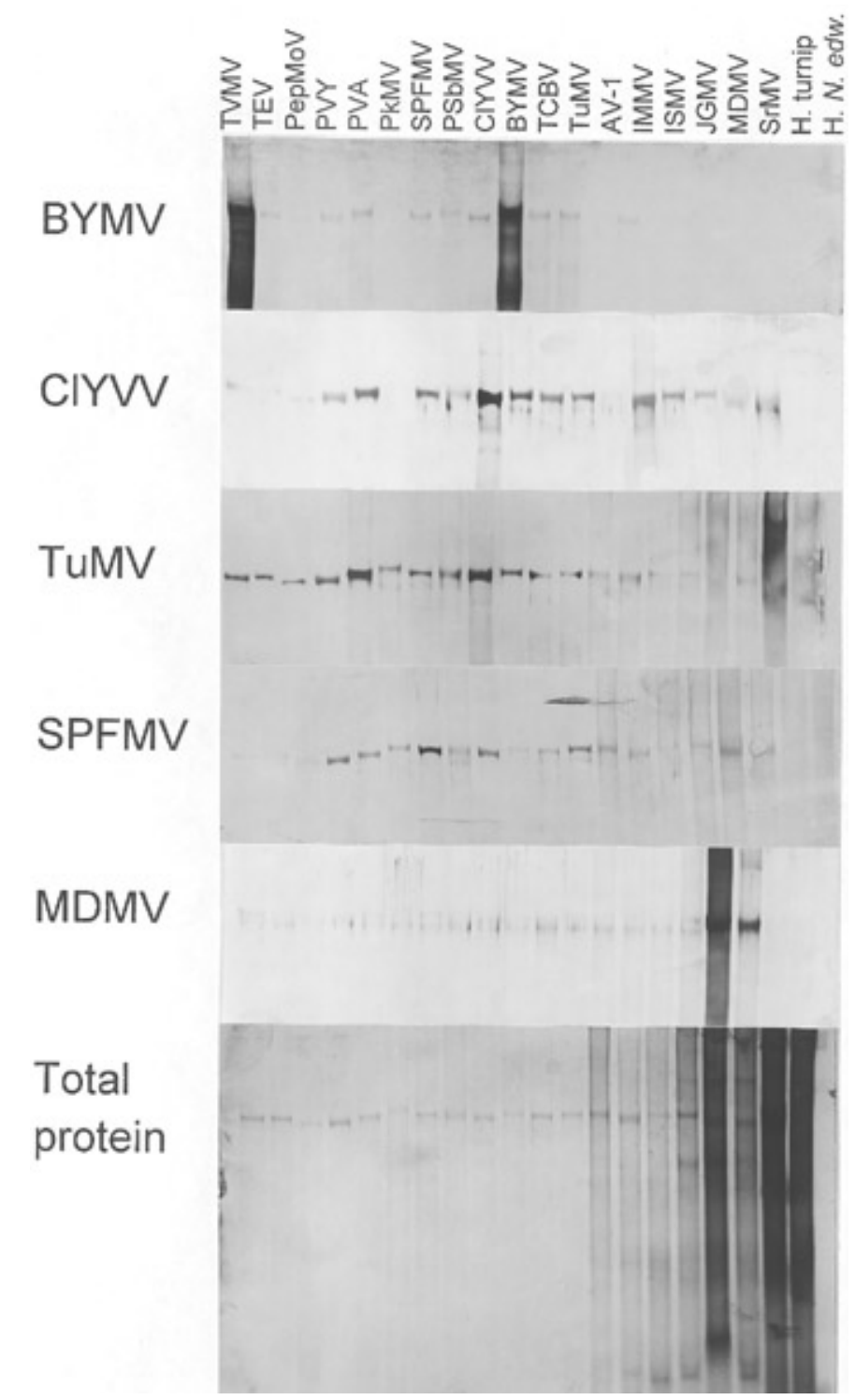

Fig. 1. Western blots and Coomassie blue-stained total protein of cytoplasmic inclusion protein (CIP) preparations and control extracts of healthy plants. Blots were reacted with antisera to CIP of bean yellow mosaic virus (BYMV); clover yellow vein virus (ClYVV); turnip mosaic virus isolate T (TuMV); sweet potato feathery mottle virus (SPFMV) isolate SPV-I; and maize dwarf mosaic virus (MDMV) isolate Minn 11. In each panel, the CIP antigens were as indicated, at approximately $1 \mathrm{mg} / \mathrm{ml}$, plus healthy turnip extract (H. turnip) and healthy Nicotiana edwardsonii extract (H. N. edw.). All antisera were diluted 1:400 and antibody reaction detected with alkaline phosphatase-conjugated goat anti-rabbit antibody as described $(17,20)$. 
highly conserved, although presence of an epitope was indicated in several sequences only when the $300 \mathrm{~N}$-terminal amino acids were examined separately. Single amino acid differences from the consensus sequence are apparently sufficient to adversely affect the flexibility of the PPV and PVY sequences, in which no potential epitope was identified. (iv) An epitope was predicted in all sequences but PPV in the region equivalent to PPV residues 234 to 242 , although only two residues are absolutely conserved in the 10 sequences for which an epitope was predicted (Fig. 2). This suggests that the glutamine residue absent in the PPV CIP might be important for antigenicity in this region. (v) A more highly conserved potential epitope was identified in the region equivalent to PPV residues 276 to 282. In this region, there were four absolutely conserved residues, with either serine or threonine and valine or isoleucine (chemically similar residues) at the other positions. (vi) PPV residues 290 to 296 partially overlap with regions identified in all other sequences except JGMV. At this position, JGMV has a six-amino-acid insertion relative to the other sequences. Other regions identified by FLEXPRO were not conserved between the sequences, despite some partial overlapping of predicted flexible regions (Fig. 2).

The domains identified by ANTIGEN were unique to each CIP, with the exception that two to five residues were conserved between
PPV residues 449 to 454 and each of the other sequences, although not all were identified by ANTIGEN (Fig. 2). The TVMV, PVA, and TuMV sequences were identical at this point, but ANTIGEN predicted an epitope only for TVMV and PVA (Fig. 2). Residues predicted to be an epitope at JGMV amino acids 345 to 350 are perfectly conserved in PepMoV and five of six residues in BYMV and TEV, but no epitope was identified except in JGMV (Fig. 2). Similarly, three to five of TEV residues 356 to 361 are conserved in each of the other CIPs, with three residues absolutely conserved; however, TEV was the only virus in which an epitope was predicted (Fig. 2). ANTIGEN also predicted an epitope for each CIP in the region similar to PPV residues 550 to 560, although the sequences are quite distinct and only two residues are conserved among the 11 sequences (Fig. 2). Two epitopes predicted by ANTIGEN and one predicted by FLEXPRO overlapped in the nine C-terminal residues of the JGMV CIP that are part of a significant extension with respect to the other CIP sequences (Fig. 2).

\section{DISCUSSION}

The cross-reactivity of the various antisera differed markedly. While four of the five antisera (those to BYMV, CIYVV, TuMV, and SPFMV CIPs) had considerable cross-reactivity, the MDMV

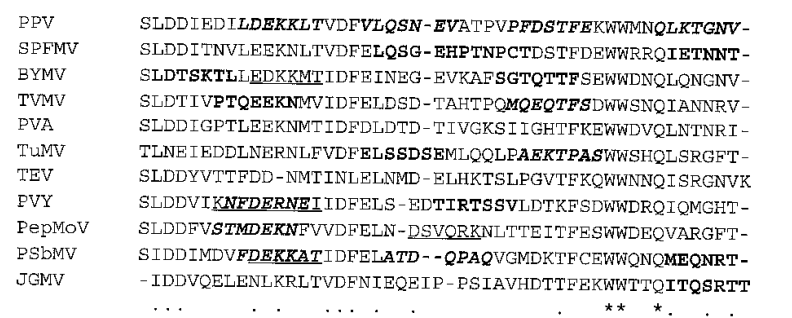

PPV IFHYRTEGHFLEFTRENAAHIANEVMHGSH-ODILIRGAVGSGKSTGLPF SPFMV ITHYRTEGVFIEFTRSNAVSVVNIIATIDA-KDILIRGAVGSGKSTGLPF BYMV ITHYRTEGQFMEETRANAQPVANEIAHNDA-NDILVRGAVGSGKSTGLPF TVMV VPHYRTEGYFMOFTRNTASAVSHOIAHNEH - KDI ILMGAVGSGKSTGLPT PVA VPHYRTEGHFMEF"TRANAPTIAHO IAHDLH-TDIMTRGAVGSGKSTGL PY TUMV IPHYRTEGKFMTFTRATATEVAGKIAHESD-KDILLMGAVGSGKSTGLPY TEV PPHYRTEGHFMEFTRDTAASVASEISHSPA-RDFLVRGAVGSGKSTGLPY PVY LPHYRTEGHFMEFTRATAVQVANDIAHSEH-LDFLVRGAVGSGKSTGLPV PEPMOV IPHYRTEGRFNEFTRATAAKVASDISISSE-RDFLIRGAVGSGKSTGL PSBMV VPHYRTGGKFIEFTRSNAASVAMEIAHTPDFSEYLIRGAVGSGKSTGLPC JGMV -THYRNKGEF IEFSRSNA IVVCNR IAHGSDSKHFLVRGNVGGKSTAIPR -THYRNKGEFIEFSRSNAIVVCNR IAHGSDSRHFLVRGNVGSGKSTAIPR
$. * * *, * * . * ._{*}^{*} .$.

FPV HLSKKGHVLLIEPTRPLAENVCKQLRGQPFNVNPTLRMRGMSTFGSTPIT SPFMV YLSRKGRVLLIEPTRPLAENVHROLGGEPFVVOATLRMRGLTVFGSHPTI YLRT BYTV TVMV PVA TuMV
TEV TEV
PVY PepMor PepMo PSBMV
JGMV

PPV

SPFMV

BYMV

TVMV

PVA

TuMv

TUMV
TEV
PVY

PepMov

PSbMV

JGMV LSNKGKVLMIESTRPL AENVEKOLKSFPFVASPTI PMRGTTSYGASPIT NLCKFGGVLLLEPTRPLAENVTKQMRGSPFFASPTLRMRNLSTFGSSPIT HLSKKGTVLLLEPTRPLAENVTKQLKSDPFHVSPTLRMR GMAVFGSTPIH HLSRKGNVLLLEPTRPLAENVHKQLSQAPFHQNT'ILRMRGLTAFGSAPIS HLSKRGRVLMLEPTRPLTDNMHKOLRSEPFNCFPTLRMRGKSTFGSSPIT HLSVAGSVLIIEPTRPLAENVFKQLSSEPFFKKFTLRMRGNSIFGSSPIS HLSTYGRVLLIEPTRPLAENVEKQLSGGPFFLKPTMRMRGNSVFGSSPIS YLSAKGRVLLLEPTRPLTEMVCAQLRGS PFHKS PSMSMRNGHTEGSTPIH YLSDKGKVLVLEPTRFLTENVCQQLQNE PWCLDFTMOMRGKSIFGSTPIT

VMTSGYALHF LANNPTYLDNYKCI IFDECHVHDASAMAFRCLESEYSYPC IMTTGFAFHYYANNPEQIGEYDF IMFDECHVHDAOAMAFRCLLKEHEFKO IMTSGYALHYYANAPAMMKEYRFVIVDECHVHDANAIAFVSLLKEYSFDG VMTTGFALHFFANNVKEFDRYQFI I IFDEFHVLDSNAIAFRNLCHEYSYNG VMTTGFALHY LANNEKML STYDF I I IDEFHVHDSNA IALRNL.LHEHNYQG VYTSGGFALNYFANNRSRIEEFDFVI FDECHVHDANAMAMRCT,THECDYSC VMTSGFALHHFARNIAEVKTYDFVI IDECHVNDASAIAFRNLLFEHEFEG VMTSGFALHYFANNRSOLAOFNFVIFDECHVLDPSAMAFRSLISVYHQAC VMTSGFALHEFANN I TQLQE IQF I I IDECHVMDASSMAFRSL I HTYHTNC VMTTGYALHFFCNNVERTREYDFVIFDECHV IDSSAMSFYCALKEYSYQG

$\begin{array}{ll}48 & \text { PPV } \\ 48 & \text { SPFMV } \\ 48 & \text { BYMV } \\ 48 & \text { TVMV } \\ 48 & \text { FVA } \\ 49 & \text { TuMV } \\ 48 & \text { TEV } \\ 48 & \text { PVY } \\ 48 & \text { PEPMOV } \\ 47 & \text { FSbMV } \\ 48 & \text { JGMV }\end{array}$

KILKVSATPPGHEVEFKTQKEVKVIVEESLSFOOFVSNLGTGCNSDILKH RILKTSATPPGREVEFTT YYPVOI KVEERLSFKAFVEAOGTGSNADVVTI KLIKVSATPPGREVEFTTQFPVTLVTEESUSFEQFVSQQGTGANCDMLDV KI I KVSATPPGRECDLTTQYPVELLIEEQISLRDFVDAQGTDAHADVVKK KLIKVSATP PGREVEFSTQYPVEIRVEDQVSFODFVKAQGNGSNLDLTSK KI I KVSATPPGREVEFSTOYPVSISTEDTLSFODFVNAOGSGSNCDVISK KVLKVSATEPGREVEFTTQFPVKLKIEEALSFQEFVSLQGTGANADVISC KVLKVSATPVGREVEFTTQQPVRLIVEDTLSFQSFVDAQGSKTNADVVQF
KVISTE KVLKVSATPPGREVEFTTQF'PVKLVVEDSLSFKTFVESQGTGSNCDMIQY KILKVSATPPGREVEFKTQFPVTIATEDSLSEDQFVQAOGSGANCDILKK KIISVSATPPG-GSEFQTEKEVDLRVFEDVSFDTFVMEQGTGSRLDAVSV

247

247

247
247

247

248

247

247
247

247 246

PPV ADNILVYVASYNEVDELSRMLVEANYYKVTKVDGRTMKVGN - - - - - - - V CDNILVYVASYNEVDQLSKMLLDRGHIVT'KVDGRTMKNGK - - - - - - T GDNILVYVASYNEVDQSLRML NERGFLVTKVDGRTTMKLGG- . . - . - - - V CDNLLVYVASYNEVDOLSKLILERHFLVTKVDGRSMKLGO- . . . . . - - V GDNILVYVASYMEVDTLSKLLIERDFKVTKVDGRTMKVGM - . - . - - - I GDN ILVYVASYNDVDSLGKLLVQKGYKVSKIDGRTMKSGG- - - - - - T GSNVLVYVSSYNEVDTLAKLLTDKNMMVTKVDGRTMKHGC- . . - . - . - I GNNILIVYVASYNEVDOLSKLLVAREFNVTKVDGRTMKHGE - . . . . . - L GHNI LVYVSSYNEVDRLSKLLVDRGEKVTKVDGRTMKLGG- . . . - . - -V GHNI LVYVSSYNEVDRLSKLLVDRGEKVTKVDGRTIMKLGG- - - - - - V
CDSILVYVASYNEVDQMSRLLNEKGYTVTKVDGRTMNGGNKTGSGLNKHI LVYVASYNEVDQMSRLLNEKGYTVTKVDGRTMNGCMK
$* * * * * * * * * \ldots *$

EIPTSGT- - - - QAKPHFVVATNI IENGVTLDIDVVVDFGLKVVPVLDI EIOTCGS - - - - - POKKHFIVATNI IENGVTLDIEAVVDFGTKVTAYLDV EIESKGS - - - - - KSKRHF IVATNI IENGVTLDIEGVVDFGLKVVPELDV EI ITKGS - - - - - SIKKEF IVATNIEENGVTLDVDVVVDFGLKVVPNLDS EI ITKGS - - . - - ANKKHF IVATNI IENGVTLDIDAVIDFGMKVVPFLDS EITTSGT - . - . - ESRKHF IVATNI IENGVTLDIDVVADFGTKVLPYLDT EI ITEGT - - - - - SVKKHF IVATN I EENGVTIDIDVVVDFGTKVVPVLDV EIVTKGT- - - - SARPHFVVATN I IENGVTLDIDVVVDFGLKVSFFLDI

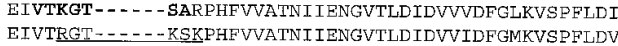
EINTSGT- - - - - AEKPHF IVRTNI IENGVTLDIDVVVDFGVKVVAELDA HVSLNETLQAQIKQHGKNF IVATN I IENGVTLNVDGVVDFGTKVVADLDV

$$
* * * * * * * * * * \ldots \ldots * * * * * *, * *
$$
IMTTGFALHLFANNVERLSEF KE I I FDECHVVDSNAMAF SCLLEEYKYNG

$\begin{array}{ll}197 & \text { FPV } \\ 197 & \text { SPFMV } \\ 197 & \text { BYMV } \\ 197 & \text { TVVNV } \\ 197 & \text { PVA } \\ 198 & \text { TUMV } \\ 197 & \text { TEV } \\ 197 & \text { PVY } \\ 197 & \text { FepMoV } \\ 197 & \text { PSbMV } \\ 197 & \text { JGMV }\end{array}$

DNRLVRYTKKS ISYGER IQRLGRVGRNKPGAALRIGFTEKGLTOIFPI I DLRALHIMSKGPISYGERIQRIGRVGRNKAGVALRIGFT'EKGLTEIPQTTA DNRLMRYTKONVSYGERIQRLGRVGRHKAGKALRIGITEKGLVKPPSVIT DNRLVSYCKIPISLGERIQRFGRVGRNKPGVALRIGETIKGLVE I PSMIA DNRMISYNKVSISYGERIORLGRVGRNRAGVALRIGHTEKGISDVPVVIA DNRMLSTTKTSINYGERIORLGRVGRHKPGHALRIGHTERGLSEVPSCI DNRAVQYNKTVVSYGERIOKLGRVGRHKEGVALRIGQTNKTLVEIPEMVA DNRS IAYNKVSVSYGERIQRLGRVGRF KKGVALRI IGHEKGI IEIPSMVA DNRSVAYNKVS I SYGERIQRLGRVGRIQKGTAIRIGHTEKGIIEI FOMIS DARTMRYNKQA ISYGERIQRLGRVGRLKDGHALR I GHTEKGITEIPVAIA DNRSI I YQK IPI SYGERVQRIGRVGRFKKGYAFR I GTTQKGIVD I PAMTA

(continued on next page)

Fig. 2. Amino acid sequence alignments of the cytoplasmic inclusion proteins of the viruses indicated, generated using CLUSTAL. Materials and Methods lists GenBank accession numbers. Amino acid residues conserved in all sequences $(*)$ and chemically similar substitutions (.) are marked under the alignment, and the conserved nucleotide binding motif is underlined (*****). Epitopes predicted by the program ANTIGEN are underlined in the individual amino acid sequence, and epitopes identified using the program FLEXPRO are marked in bold in the individual sequences. Epitopes predicted by FLEXPRO only from separate consideration of the $\mathrm{N}$-terminal 300 amino acids are shown in bold italics. The predicted common epitopes cluster in the $\mathrm{N}$-terminal 300 residues and the virus-specific epitopes cluster in the C-terminal domains. 
CIP antiserum cross-reacted to a much lesser degree. There were only strong reactions with the homologous antigen and that of SrMV (Fig. 1). No reaction to JGMV CIP was apparent; a minor band of uniform mobility observed with all other preparations (Fig. 1) was apparently due to reaction with a conserved host protein. This is in accord with the results of Jensen and Staudinger (25), who reported that MDMV-A (type strain) and MDMV isolate Minn-11 were grouped together and that there was moderate cross-reaction with isolates MDMV-B and I-188, but negligible reaction with KS-1 and MDMV-O CIPs. In other reports, isolates KS-1 and MDMV-O have been identified as strains of JGMV $(33,41)$ and MDMV-B as an isolate of SCMV (41). Thus, the results of Jensen and Staudinger (25) may be restated: there was cross-reaction between MDMV and SCMV, but negligible cross-reaction with JGMV. SrMV was not represented in the tests of Jensen and Staudinger (25); the results presented here show that the SrMV CIP also cross-reacts with MDMV CIP antiserum. The range of cross-reactions of the four more broadly reactive antisera were quite distinct. While the strongest reactions of the BYMV, ClYVV, and SPFMV CIP antisera were clearly to the homologous antigens, this was not the case with the TuMV CIP antiserum. The reason for this is not clear, but may reflect the fact that the true homologous isolate was not available. Differences in the specificity of individual CIP antisera were reported using gel diffusion techniques; two antisera to each virus CIP were tested, and differences in specificity (or cross-reactivity) were observed between the sera against each of PepMoV and PVY CIPs (37). This was presumably due to differences in the response of individual animals and in the time between immunization and antiserum collection (37).
There was typically lower reactivity of the dicot-infecting potyvirus (BYMV, ClYVV, TuMV, and SPFMV) CIP antisera to the CIPs of AV-1, IMMV, ISMV, and the three viruses from graminaceous hosts (JGMV, MDMV, and SrMV), with the exception of the ClYVV CIP antiserum (Fig. 1), suggesting that there may be some consistent difference between the CIPs of viruses naturally restricted to monocot hosts and those primarily infecting dicots. However, there were no other obvious host-related relationships or strong reciprocal relationships. For example, the BYMV CIP antiserum reacted very strongly with the TVMV CIP, as well as the homologous antigen, and to a number of apparent breakdown products of each (Fig. 1). The only other antiserum to yield significant reaction to breakdown products was the ClYVV CIP antiserum (Fig. 1) and, despite the close relationship between BYMV and CIYVV, there was no stronger a cross-reaction between these than between less-closely related antigens. There is no obvious explanation for the weak reactivity of the BYMV and CIYVV CIP antisera to PkMV or AV-1 CIPs. It is possible that the serological similarity of BYMV and ClYVV may explain the similarity of the reactions of these antisera to PkMV and AV-1 CIPs.

Examination of the CIP sequences of 11 potyviruses revealed many regions of amino acid homology (Fig. 2). However, none of the regions identified by the program ANTIGEN, based on local regions of high hydrophilicity and thus predicted to be antigenic (23), were conserved between sequences; indeed, only one predicted region was fully conserved between multiple sequences (PPV amino acids 449 to 454 and TVMV, PVA, and TuMV), and an epitope was predicted in four of the sequences, but not in TuMV (Fig. 2). The sequence in the region of amino acids 550 to 560 contains a

Fig. 2. (continued from preceding page)

\begin{tabular}{|c|c|c|}
\hline PPV & TEAAFLCFTYGLPVMTNGVSTSLLAMCTVKQARTMQQFELSPFYTVALVR & 432 \\
\hline SPFMV & TEAAFLCFAYGLFVMTPNVSTSLLSTCTVKQARTMLQFELTPFYMVNIVVR & 432 \\
\hline BYMV & TEAAFYCFAYGLPVMAEGVTPSLLSKCTVQQARSMMSFELPIMYTVNLVR & 432 \\
\hline TVMV & TEAAFLCFVYGLJPVTTQNVSTS ILSOVSVRQARVMCQFELPIFYTAHLVR & 432 \\
\hline PVA & TQAAFLGEVYGLFISTQSVTTQVLSNVTLKQARTMVQFELPIFYMAHLVR & 432 \\
\hline TuMV & TEAALKCETYGLPVITNNVSTS I LGNVTVKOARTMSVFEITPFYTSOVVR & 433 \\
\hline TEV & TEAAFLCFMYNLPVTTQSVSTTLIENAT'LLQARTMAQFELSYFYTINFVR & 432 \\
\hline FVY & TEAALACFAYNLPVMTGGVSTSLIGNCTVRQVKTMQQFELSPFFIQNFVA & 432 \\
\hline PepMov & TEAALYCFAYNLPVMSSGVSTSMIKNCT I PQVRTMHTEELSPFFMYNFVS & 432 \\
\hline ESBMV & VESAFQCFAYGLPVMTS SNVSTSIIGNCTVKQARTMMNFELSPFFTVELVK & 432 \\
\hline \multirow[t]{2}{*}{ JGMV } & TEAAFLCFAYGLPVITHNVSTTHLSHVTSAQARTMLQFELPIFMMSELVK & 446 \\
\hline & 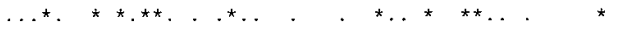 & \\
\hline FPV & FDGTMHOE IFRLLKSYRLRDSEVILNKLAI PNSNVCGWMSVRDYKRQGCN & 482 \\
\hline SPFMV & YDGSMHFA IHS ILKKYKIRDAFTDLNKMA I PNRGVTGWLSVGEYVKSGKR & 482 \\
\hline BYMV & FDGTMHPA IHNLLKPYKLRDSNVVLNKMAI PHGNVRNWPTVRDFKYVGVR & 482 \\
\hline TVMV & YDGAMHPA I HNATKRFKLRDSEINLNTLAI PTSSSKTWYTSKCYKQLVGR & 482 \\
\hline PVA & YDGTMHPA I HNELKKYKLRDSEIQLRKLAI FSKCVP IWMTGKAYRLLTHN & 482 \\
\hline TuMv & YDGSMHPQVHALLKRFKLRDSEIVLTKLAIIFNRGVNAGSQPVSMHDSVQM & 483 \\
\hline TEV & FDGSMHPVIHDKLKRFKLHTCETFLNKLAI FNKGLSSWLTSGEYKRLGY I & 482 \\
\hline PVY & HDGSMHPVIHDILKKYKLRDCMTPLCDQSI PYRASSTWLSVSEYERLGVA & 482 \\
\hline PepMov & HDGTMHPVVHETLKRYKLRDSVI FLSESSIPYRASSDW ITAGDYRRI GVK & 482 \\
\hline PSBMV & YNGTMNPE IHKILVPYKLRDS SNQLCKEAIPNSGVSRWHTAHEYISHGIV & 482 \\
\hline \multirow[t]{2}{*}{ JGMV } & YDGHMHPAIHEIEKQEKLRDSSISLRDTALPQNASDLWLSVGAYKKLGYR & 496 \\
\hline & $*^{*} \ldots . \quad * \ldots * \ldots \quad * \ldots *$ & \\
\hline PPV & LDLDENI - RVPFYVKDIPETLHERIWQAVETHKSDAGF GRICSSSACKIA & 531 \\
\hline SPFMV & MDIDDSV-RIPFLINFSMPERLHVDIWDAITKYKHEAGFGRISCINSCKVA & 531 \\
\hline BYMV & LDAPEDT -RVPFYARDIFDKLHKEVFEVCSKYKGDAGFSKLNVVNACKIA & 531 \\
\hline TVMV & LDIPDEI - KIPFYTKEVPEKVPEQIWDVMVKFSSDAGFGRMTSAAACKVA & 531 \\
\hline PVA & SQIPDDV-RVPFLTKEIFDKLHENVWAIVEKFKCDAGIGRMTSAQASKVA & 531 \\
\hline TulvV & LKIGVTL-RIPFMCRDIPEKLHLDMWDVVVKFKGDAGFGRLSSS-ASKVA & 531 \\
\hline TEV & AE-DAGI - R I PFVCKEI PDSLHEE IWHIVVAHKGDSGIGRLTSVQAAKVV & 530 \\
\hline PVY & LEIPKQV-KIAFHIKEIPPKLHEMLWETVVKYKDVCLFPSIRASSISKIA & 531 \\
\hline PepMov & LDIPDET-RIAFHIKTFHRKFTNNLWESVLKYKASAAF ETLRSSSITKIA & 531 \\
\hline PSbMV & LETLKSVDRIPFYLKGVPEKVYEKIWNAVCVFKSDSGFGRMSTASACNVA & 532 \\
\hline \multirow[t]{2}{*}{ JGMV } & IDLPDDC-KIPYYVRGVSAKMYEQIWNAVKDFRQTCCMRRMISSCAGEIA & 545 \\
\hline & $\cdots$ & \\
\hline PPV & YTLQTDIHS IPRT I KI IDALLEOERTKQAHFRAMTSQSCSSSNFSLSSIT & 581 \\
\hline SPFMV & YTLQTDLYAIPRTIKI IDAL I ADEMRKKEHYKTITGRTVSSSSPTLNSIA & 581 \\
\hline BYMV & YTLQTDPSS IQRT IKILDEL I SREOOKREYFONVANTSCAGSSYSLSNI I & 581 \\
\hline TVMV & YTLQTDIHS IQRTVQI IDRLIENEMKKRNHFNLVVNQSCSSHFMSLSSIM & 581 \\
\hline PVA & YTLETDIHSVQRT ILI IDQLIEREMOKQSHFEMVTNQSCSSGMLSLQTMM & 581 \\
\hline TuMV & YTLQTDVNSIQRTVTIIDTLIAEERRKOEYFKTVTSNCVSSSNFSLQSIT & 581 \\
\hline TEV & YTLQTDVHS IARTLACINRRIADEQMKQSHFEAATGRAF SFTNYSIQSIF & 580 \\
\hline PVY & YTLRTDLFAIPRTLILVERLLEEERVRQSQFRSLIDEGCSS-MFSIVNLT & 580 \\
\hline Pepmov & YTLSTDLYAIPRTLAVVESLLEDERTKOYOFKSLIDNGCSS-MFSVVGIS & 580 \\
\hline PSbMV & YTLKTDELS ITRT IAHIDALLI EEOEKKSQFDLMSSHVTNSSSISLAGLV & 582 \\
\hline JGMV & YTUQTDVNAIPRTLAIIDGLIKEEOIKHSHFQSISANSTSSYNFSLNGIM & 595 \\
\hline
\end{tabular}

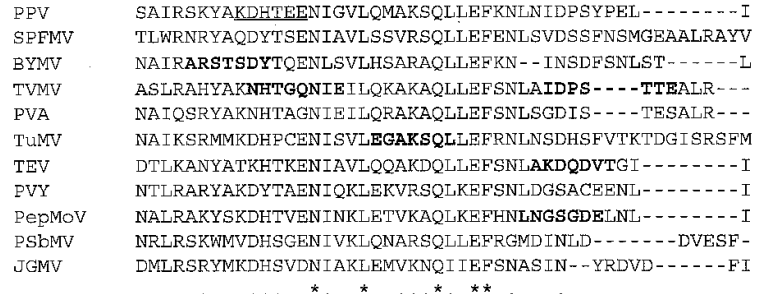
QDFNHLETIY-- LKRYESLQFVHH---

KRFESLQFVHH -

RKFGCAETVRC-

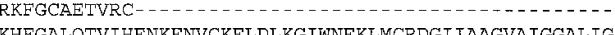
KHFGALOTVIHENKENVCKELDLKG IWNEKIMCRDGIIAAGVAIGGALIG

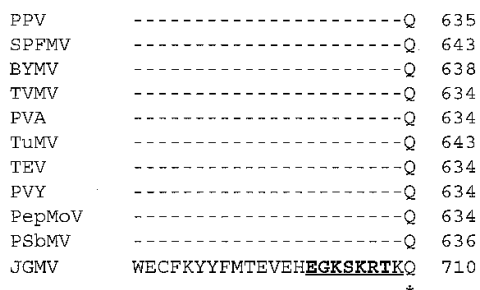

581 
predicted epitope in each of the four CIPs examined, but with little sequence identity (Fig. 2). The most conserved region predicted to be antigenic by virtue of its flexibility (program FLEXPRO) (26) was PPV amino acids 88 to 94 . This overlaps the predicted nucleotide binding motif (NTBM) of the CI, which has been demonstrated to have helicase activity (28). The nucleotide binding site must be surface accessible and is presumably extremely conserved between the CIPs of different potyviruses; indeed, the NTBM of the potyvirus CI was first recognized by its similarity to those reported for other viruses $(8,15)$. It is, therefore, highly likely that antisera to any potyvirus CIP will contain antibodies to the NTBM and that this is, at least in part, responsible for the observed crossreactivity. Indeed, Baunoch et al. $(5,36)$ reported that TEV CIP has several epitopes in common with narcissus yellow stripe and wheat streak mosaic potyvirus CIPs and also with the $126-\mathrm{kDa}$ protein of TMV and the NS3 protein of flaviviruses. These proteins also contain a NTBM and other sequences associated with helicase and ATPase activity (15). The lack of cross-reactivity of antisera to JGMV (25) and MDMV CIPs (25) may reflect the stage of immunization at which the serum was collected or the immune response of an individual animal, as noted previously (37). However, there is a single amino acid difference, an Ala for Gly substitution, at the C-terminal side of the NTBM that results in the predicted JGMV epitope being shifted one residue towards the N-terminus (Fig. 2). It is, therefore, possible that antisera raised against the JGMV CIP would not recognize the epitope of other potyviruses due to resulting conformational differences.

Many of the other potentially antigenic sites identified here (discussed above) (Fig. 2) differ considerably between the 11 CIP sequences examined and may explain the differential cross-reactivity observed $(25,37,44)$. The degree of cross-reactivity observed is not likely to be useful in determining relationships or identity between potyvirus isolates. Purcifull and Hiebert (36) noted that CIPs have both conserved and unique epitopes and that some monoclonal antibodies have been produced to CIPs of papaya ringspot and watermelon mosaic viruses $(3,4,43)$, although no cross-reactivity tests were reported. Monoclonal antibodies would certainly allow more detailed examination of the serological relationships between the CIPs of different potyviruses, as would further studies similar to those reported by Baunoch et al. (5). However, the apparent differentiation observed here between potyviruses primarily infecting monocots and those infecting dicots may lead to identification of functional differences, especially if the differences are localized to specific domains of the CIP. It is significant that the JGMV CIP has a C-terminal extension of about 60 amino acids, as well as internal insertions of nine and six amino acids, relative to 10 other (primarily dicot-infecting) potyviruses examined (Fig. 2). Such differences might reflect the organization of membranes in monocots versus dicots, as the CIP is thought to function as the membrane-binding component of the viral replication complex (8) and may be involved in vesicle production and cell-to-cell virus transport $(6,30)$. It is noteworthy that most of the distinct, virus-specific epitopes predicted are in the C-terminal region (Fig. 2), whereas the helicase-associated motifs and most of the shared epitopes are all in the N-terminal half of the CIP (29). This contrasts with the serological relationships of potyvirus $\mathrm{CP}$ genes, in which most of the virus-specific epitopes are in the N-terminal domain (42).

There is relatively little amino acid identity in the C-terminal 230 residues of the CIP, with only scattered residues that are conserved in all 11 CIP sequences examined. It is probable that the diversity in this part of the CIP contributes to the formation of structurally different CIs that have been characterized and subgrouped by Edwardson and colleagues $(10,11,13)$. Another possibility is specific interaction with the equally virus-specific $\mathrm{N}$-terminal sequence of the viral CP. Langenberg (30) has demonstrated that $\mathrm{CP}$ was specifically associated only with homologous CIP at an early stage of infection in plants that were infected with a mixture of serologically distinct potyviruses and postulated that $\mathrm{CI}$ functioned to direct virions to plasmodesmata for transmission to adjacent cells. The functional significance of the variability in the C-terminal domains of the CIP, and of the types of inclusions induced by different viruses, remains to be determined. It has been shown that different isolates of a particular potyvirus can induce CIs of different morphology, which can probably be explained by mutations in the CI gene (12). However, no correlation has previously been established between CI morphology, vectors, host range, or serology. It may be significant, in light of the results presented here and by Jensen and Staudinger (25), that MDMV, SCMV, and SrMV all fall into subdivision III based on inclusion type, whereas JGMV (shown less cross-reactive with CIP antisera) is classified into subdivision I (12). Further examination of CI sequences and functional analysis of the $\mathrm{C}$-terminal domains may elucidate the significance of these results. Exchange of CI and CP genes in infectious potyviral clones would be one means of determining the interactions between these two proteins.

\section{ACKNOWLEDGMENTS}

I thank F. W. Zettler for generous gifts of antisera; S. G. Jensen for his generous gifts of antiserum, seed, and virus isolates; L. McDaniel for preparing the antiserum to sweet potato feathey mottle virus cytoplasmic inclusion protein; and V. Hari, D. Purcifull, and S. G. Jensen for critical review of the manuscript.

\section{LITERATURE CITED}

1. Allison, R., Johnston, R. E., and Dougherty, W. G. 1986. The nucleotide sequence of the coding region of tobacco etch virus genomic RNA: Evidence for the synthesis of a single polyprotein. Virology 154:9-20.

2. Alper, M., Salomon, R., and Loebenstein, G. 1984. Gel electrophoresis of virus-associated polypeptides for detecting viruses in bulbous irises. Phytopathology 74:960-962.

3. Baker, C. A. 1989. Production and characterization of polyclonal and monoclonal antibodies to three virus-induced proteins of papaya ringspot virus type W. Ph.D. dissertation. University of Florida, Gainesville.

4. Baker, C. A., and Purcifull, D. E. 1990. Reactivity of two monoclonal antibodies to the cylindrical inclusion protein of papaya ringspot virus type W. (Abstr.) Phytopathology 80:1033.

5. Baunoch, D. A., Das, P., and Hari, V. 1991. Epitope analysis of the CIP of tobacco etch virus. (Abstr.) Phytopathology 81:1147.

6. Calder, V. L., and Ingerfeld, M. 1990. The roles of the cylindrical inclusion protein of a potyvirus in the induction of vesicles and in cell-to-cell spread. J. Struct. Biol. 105:62-66.

7. Domier, L. L., Franklin, K. M., Shahabuddin, M., Hellmann, G. M., Overmeyer, J. H., Hiremath, S. T., Siaw, M. F. E., Lomonossoff, G. P., Shaw, G. P., and Rhoads, R. E. 1986. The nucleotide sequence of tobacco vein mottling virus RNA. Nucleic Acids Res. 14:5417-5430.

8. Domier, L. L., Shaw, J. G., and Rhoads, R. E. 1987. Potyviral proteins share amino acid sequence homology with picorna-, como- and caulimoviral proteins. Virology 158:20-27.

9. Dougherty, W. G., and Hiebert, E. 1980. Translation of potyviral RNA in rabbit reticulocyte lysate: Cell-free translation strategy and a genetic map of the potyviral genome. Virology 104:183-194.

10. Edwardson, J. R. 1974. Some Properties of the Potato Virus Y Group. Fla. Agric. Exp. Stn. Monogr. No. 4.

11. Edwardson, J. R., and Christie, R. G. 1991. The Potyvirus Group. Fla. Agric. Exp. Stn. Monogr. No.16, Vol. 1-4.

12. Edwardson, J. R., and Christie, R. G. 1996. Cylindrical Inclusions. Fla. Agric. Exp. Stn. Bull. 894.

13. Edwardson, J. R., Christie, R. G., and Ko, N. J. 1984. Potyvirus cylindrical inclusions-Subdivision IV. Phytopathology 74:1111-1114.

14. Edwardson, J. R., Christie, R. G., Purcifull, D. E., and Petersen, M. A. 1993. Inclusions in diagnosing plant virus diseases. Pages 101-128 in: Diagnosis of Plant Virus Diseases. R. E. F. Matthews, ed. CRC Press, Boca Raton, FL.

15. Gorbalenya, A. E., and Koonin, E. V. 1989. Viral proteins containing the purine NTP-binding sequence pattern. Nucleic Acids Res. 17:8413-8440.

16. Hammond, J. 1989. Antisera to cytopasmic inclusion of potyvirus contain cross-reactive antibodies. (Abstr.) Phytopathology 79:1174.

17. Hammond, J. 1990. Western blotting and the use of membranes to absorb antisera and to affinity purify antibodies. Pages 269-279 in: Serological Methods for Detection and Identification of Viral and Bacterial Plant Pathogens: A Laboratory Manual. R. Hampton, E. Ball, and S. De Boer, eds. The American Phytopathological Society, St. Paul, MN. 
18. Hammond, J., and Chastagner, G. A. 1988. Natural infection of tulips with turnip mosaic virus and a potyvirus serologically related to tulip breaking virus in the USA. Acta Hortic. 234:235-242.

19. Hammond, J., and Hull, R. 1981. Plantain virus X: A new potexvirus from Plantago lanceolata. J. Gen. Virol. 54:75-90.

20. Hammond, J., and Jordan, R. L. 1990. Dot blots (viruses) and colony screening. Pages 237-248 in: Serological Methods for Detection and Identification of Viral and Bacterial Plant Pathogens: A Laboratory Manual. R. Hampton, E. Ball, and S. De Boer, eds. The American Phytopathological Society, St. Paul, MN.

21. Hammond, J., and Lawson, R. H. 1988. An improved purification procedure for preparing potyviruses and cytoplasmic inclusions from the same tissue. J. Virol. Methods 20:203-217.

22. Hiebert, E., Purcifull, D. E., Christie, R. G., and Christie, S. R. 1971. Partial purification of inclusions induced by tobacco etch virus and potato virus Y. Virology 43:638-646.

23. Hopp, T. P., and Woods, K. R. 1981. Prediction of protein antigenic determinants from amino acid sequences. Proc. Natl. Acad. Sci. U.S.A. 78:3824-3828.

24. Jensen, S. G., Long-Davidson, B., and Seip, L. 1986. Size variation among proteins induced by sugarcane mosaic viruses in plant tissue. Phytopathology 76:528-532.

25. Jensen, S. G., and Staudinger, J. L. 1989. Serological groupings of 6 strains of sugarcane mosaic virus. (Abstr.) Phytopathology 79:1215.

26. Karplus, P. A., and Schulz, G. E. 1985. Prediction of chain flexibility in proteins. Naturwissenschaften 72:212-213.

27. Kumar, B. V., Lakshmi, M. V., and Atkinson, J. P. 1985. Fast and efficient method for detection and estimation of protein. Biochem. Biophys. Res. Comm. 133:883-891.

28. Lain, S., Riechmann, J. L., and Garcia, J. A. 1990. RNA helicase: A novel activity associated with a protein encoded by a positive strand RNA virus. Nucleic Acids Res. 18:7003-7006.

29. Lain, S., Riechmann, J. L., Martin, M., and Garcia, J. A. 1989. Homologous potyvirus and flavivirus proteins belong to a superfamily of helicaselike proteins. Gene 82:357-362.

30. Langenberg, W. G. 1986. Virus protein association with cylindrical inclusions of two viruses that infect wheat. J. Gen. Virol. 67:1161-1168.

31. Maiss, E., Timpe, U., Brisske, A., Jelkmann, W., Casper, R., Himmler, G., Mattanovich, D., and Katinger, H. W. D. 1989. The complete nucleotide sequence of plum pox virus RNA. J. Gen. Virol. 70:513-524.

32. McDonald, J. G., and Hiebert, E. 1975. Characterization of the capsid and cylindrical inclusion proteins of three strains of turnip mosaic virus.
Virology 63:295-303.

33. McKern, N. M., Shukla, D. D., Toler, R. W., Jensen, S. G., Tosic, M., Ford, R. E., Leon, O., and Ward, C. W. 1991. Confirmation that the sugarcane mosaic virus subgroup consists of four distinct potyviruses by using peptide profiles of coat proteins. Phytopathology 81:1025-1029.

34. Mowat, W. P., Dawson, S., and Duncan, G. H. 1989. Production of antiserum to a non-structural potyviral protein and its use to detect narcissus yellow stripe and other potyviruses. J. Virol. Methods 25:199-210.

35. Nagel, J., Zettler, F. W., and Hiebert, E. 1983. Strains of bean yellow mosaic virus compared to clover yellow mosaic virus in relation to gladiolus production in Florida. Phytopathology 73:449-454.

36. Purcifull, D. E., and Hiebert, E. 1992. Serological relationships involving potyviral non-structural proteins. Arch. Virol. 5(suppl.):97-122.

37. Purcifull, D. E., Hiebert, E., and McDonald, J. G. 1973. Immunochemical specificity of cytoplasmic inclusions induced by viruses in the potato Y group. Virology 55:275-279.

38. Quiot-Douine, L., Purcifull, D. E., Hiebert, E., and de Mejia, M. V. G. 1986. Serological relationships and in vitro translation of an antigenically distinct strain of papaya ringspot virus. Phytopathology 76:346-351.

39. Robaglia, C., Durand-Tardif, M., Tronchet, M., Bouzadin, G., AstierManifacier, S., and Casse-Delbart, F. 1989. Nucleotide sequence of potato virus Y (N strain) genomic RNA. J. Gen. Virol. 70:935-947.

40. Shukla, D. D., Frenckel, M. J., and Ward, C. W. 1991. Structure and function of the potyvirus genome with special reference to the coat protein coding region. Can. J. Plant Pathol. 13:178-191.

41. Shukla, D. D., Tosic, M., Jilka, J., Ford, R. E., Toler, R. W., and Langham, M. A. C. 1989. Taxonomy of potyviruses affecting maize, sorghum, and sugarcane in Australia and the United States as determined by reactivities of polyclonal antibodies directed towards virus-specific N-termini of coat proteins. Phytopathology 79:223-229.

42. Shukla, D. D., Ward, C. W., and Brunt, A. A. 1994. The Potyviridae. CAB International, Wallingford, United Kingdom.

43. Suzuki, N., Kudo, T., Shirako, Y., Ehara, Y., and Tachibana, T. 1989. Distribution of cylindrical inclusion, amorphous inclusion and capsid proteins of watermelon mosaic virus 2 in systemically infected pumpkin leaves. J. Gen. Virol. 70:1085-1091.

44. Suzuki, N., Shirako, Y., and Ehara, Y. 1990. Isolation and serological comparison of virus-coded proteins of three potyviruses infecting cucurbitaceous plants. Intervirology 31:43-49.

45. Yeh, S.-D., and Gonsalves, D. 1984. Purifiction and immunological analyses of cylindrical-inclusion protein induced by papaya ringspot virus and watermelon mosaic virus I. Phytopathology 74:1273-1278. 